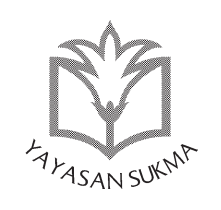

SUKMA: JURNAL PENDIDIKAN

ISSN: 2548-5105 (p), 2597-9590 (e)

Volume 3 Issue 1, Jan-Jun 2019, pp. 117-136

https://doi.org/10.32533/03106.2019

www.jurnalsukma.org

\title{
PENGARUH GLOBALISASI \\ DAN ERA DISRUPSI TERHADAP \\ PENDIDIKAN DAN NILAI-NILAI KEISLAMAN
}

\section{Ali Fikri Cholil}

Universitas Islam Negeri Sunan Kalijaga Yogyakarta, Indonesia email:alifikri1983@gmail.com

\section{Abstraks}

Globalisasi telah menghilangkan sekat-sekat antar negara; globalisasi juga telah mempersatukan dunia dalam satu komunitas "perkampungan dunia" atau global village. Kesatuan komunitas dalam perkampungan dunia itu hampir mencakup seluruh aspek kehidupan. Aspek-aspek itu telah mempengaruhi kehidupan manusia, baik dalam skala pribadi, keluarga, dan masyarakat, bahkan dalam skala antar budaya, agama, profesi, dan bahkan antar bangsa. Era disrupsi merupakan bagian dari globalisasi, sebagai akibat dari digitalisasi dan evolusi teknologi. Tulisan ini mem- 
fokuskan pada pengaruh globalisasi dan era disrupsi terhadap pendidikan dan nilai-nilai keislaman. Tulisan ini menegaskan bahwa globalisasi dan era disrupsi bisa didialogkan kembali dengan masyarakat Islam masa kini tanpa meredupkan nilai-nilai keislaman yang telah ada.

Kata Kunci: globalisasi, era disrupsi, pendidikan Islam, nilainilai keislaman

\section{A. Pendahuluan}

Kata globalisasi yang pertama kali dipopulerkan oleh Theodore Levitte pada tahun 1985 ini belum terdefinisikan secara lengkap. Masing-masing pengkajinya mengedepankan definisi kerja (work definition) menurut sudut pandang dan tinjauan masing-masing. Ada yang melihatnya sebagai suatu proses sosial, proses sejarah atau proses alamiah yang akan membawa seluruh bangsa dan negara di dunia semakin terikat satu sama lain, mewujudkan suatu tatanan kehidupan baru atau kesatuan ko-eksistensi dengan menyingkirkan batas-batas geografis, ekonomi, dan budaya masyarakat. Globalisasi merupakan proses dimana hilangnya sekat-sekat atau batas-batas antar negara dalam setiap aspek kehidupan seperti ekonomi, politik, sosial, dan budaya. Dengan begitu dapat kita pahami, globalisasi menjadikan orang melebur menjadi satu dengan semua orang di berbagai belahan dunia (Harahap 2015).

Ada beberapa konotasi globalisasi yang dipahami masyarakat dunia. Pertama, globalisasi sebagai internasionalisasi, meningkatnya hubungan internasional. Masing-masing negara tetap mempertahankan identitasnya, namun semakin tergantung satu sama lain. Kedua, globalisasi dipahami sebagai liberalisasi, semakin diturunkannya batas antar negara, misalnya hambatan tarif ekspor impor, lalu lintas devisa, maupun imigrasi. Ketiga, globalisasi sebagai universalisasi, semakin tersebarnya hal-hal yang berkaitan dengan material maupun immaterial ke seluruh 
dunia. Pengalaman lokal dapat menjadi gambaran dari pengalaman seluruh dunia. Keempat, westernisasi, semakin menyebarnya pikiran dan budaya barat hingga mengglobal. Kelima, globalisasi dipahami sebagai hubungan antar negara yang bersifat transplanetris dan suprateritorialitas, memiliki status analogi sendiri bukan sekedar gabungan negara-negara.

Globalisasi telah mempersatukan dunia dalam satu komunitas "perkampungan dunia" atau global village. Kesatuan manusia dan peradabannya dalam perkampungan dunia itu hampir mencakup seluruh aspek kehidupan, meliputi; aspek ekonomi (economic globalization), aspek politik (politic globalization), aspek pendidikan (education globalization), aspek kebudayaan (cultural globalization), aspek keagamaan (religious globalization), aspek pengetahuan dan informasi (knowledge and information globalization). Aspek-aspek ini akan dan telah mempengaruhi pergaulan kehidupan manusia, baik dalam skala lokal seperti antar pribadi, keluarga, dan masyarakat. Bahkan dalam skala yang lebih luas seperti antar budaya, agama, profesi, dan bahkan antar bangsa.

Kompleksitas pengaruh ini membuat setiap komunitas termasuk umat islam secara tak terelakkan harus mengkaji dan menyikapi dampak-dampak globalisasi tersebut terhadap kehidupan dan pergaulan mereka, sebab kebudayaan bangsa yang kuat dan cerdas akan memunculkan dan mewarnai globalisasi itu. Sebaliknya, peradaban yang lemah tidak mampu mengakomodasi globalisasi bahkan digilas dan hanya menahankan efek negatifnya.

\section{B. Globalisasi dan Era Disrupsi}

Ada beberapa ciri yang dapat dipandang sebagai fenomena globalisasi dunia, diantaranya: Pertama, keterkaitan antar negara yang semakin meningkat seperti ditunjukkan oleh hilir mudiknya kapal-kapal pengangkut barang antar negara. Kedua, perubahan dalam konstalasi ruang dan waktu. Komunikasi global terjadi begitu cepat yang ditandai dengan perkembangan tekno- 
logi informasi seperti hand phone, televisi satelit, dan internet. Ketiga, saling ketergantungan produksi dan pasar ekonomi negara-negara yang berbeda sebagai akibat dari pertumbuhan perdagangan internasional serta pengaruh perusahaan multinasional. Keempat, peningkatan interaksi kultur melalui perkembangan media massa terutama televisi, film, musik, dan transmisi berita internasional. Kelima, peningkatan masalah bersama dalam berbagai bidang seperti lingkungan hidup, pemanasan global, krisis multinasional, dan lain sebagainya.

Globalisasi dengan ciri yang disebutkan diatas telah menimbulkan pengaruh yang tidak terperikan bagi manusia. Kennedy dan Kohen menyimpulkan bahwa transformasi ini secara tak terelakkan telah membawa kita pada globalisme, sebuah kesadaran dan pemahaman baru bahwa dunia adalah satu. Bahkan lebih realistik lagi Giddens menyindir bahwa kebanyakan kita sadar bahwa diri kita sebenarnya turut ambil bagian dalam sebuah dunia yang harus berubah tanpa terkendali yang ditandia dengan selera dan keterkaitan akan hal yang sama, perubahan, dan ketidakpastian.

Saat ini kita sedang menghadapi fenomena disrupsi, yang merupakan bagian dari globalisasi. Dalam Kamus Besar Bahasa Indonesia (KBBI), disrupsi didefinisikan hal tercabut dari akarnya. Jika diartikan dalam kehidupan sehari-hari, disrupsi adalah sedang terjadi perubahan fundamental atau mendasar, yaitu evolusi teknologi yang menyasar sebuah celah kehidupan manusia (Kasali 2018).

Digitalisasi merupakan akibat dari evolusi teknologi (terutama informasi) yang mengubah hampir semua tatanan kehidupan, termasuk tatanan dalam berusaha (bisnis) dan pendidikan. Sebagian pihak mengatakan bahwa disrupsi adalah sebuah ancaman. Namun banyak pihak pula mengatakan kondisi saat ini adalah peluang. Era disrupsi ini merupakan fenomena ketika masyarakat menggeser aktivitas-aktivitas yang awalnya dilakukan di dunia nyata, beralih ke dunia maya. Fenomena ini berkembang pada perubahan pola mulai dari dunia bisnis, perbankan, trans- 
portasi, sosial masyarakat bahkan sampai berpengaruh ke dunia pendidikan.

Disrupsi (disruption) istilah yang dipopulerkan oleh Clayton Christensen dan Michael Porter sebagai kelanjutan dari tradisi berpikir "harus berkompetisi, untuk bisa menang (for you to win, you've got to make somebody lose)". Kedua profesor Harvard Business School ini telah mendominasi dunia bisnis dalam 22-37 tahun terakhir. Perusahaan dari segala jenjang dan industri perlu menerapkan teknologi baru guna menciptakan model-model bisnis canggih yang mampu menghadirkan nilai yang lebih besar bagi para pelanggan mereka karena ada lawan-lawan yang tidak kelihatan yang berusaha untuk menggeser kedudukan mereka (Kasali 2018).

Lawan-lawan tersebut tidak memiliki bentuk fisik yang sama dengan perusahaan-perusahaan yang besar, tetapi bisa menyaingi mereka. Dengan meluasnya gaya hidup digital, para konsumen kini dimanjakan dengan berbagai pilihan dan memiliki ekspektasi yang jauh lebih tinggi dari sebelumnya. Di era disrupsi kita harus mempunyai pilihan, membentuk ulang (reshape) atau menciptakan yang baru (create). Jika kita memutuskan untuk reshape, maka kita bisa melakukan inovasi dari produk atau layanan yang sudah dimiliki. Sedangkan jika ingin membuat yang baru (create), kita harus berani memiliki inovasi yang sesuai dengan kebiasaan konsumen.

\section{Pengaruh Negatif Globalisasi terhadap Pendidikan}

\section{Komersialisasi Pendidikan}

Era globalisasi mengancam kemurnian dalam pendidikan. Banyak didirikan sekolah-sekolah dengan tujuan utama sebagai media bisnis. John Micklethwait menggambarkan sebuah kisah tentang pesaingan bisnis yang mulai merambah dunia pendidikan dalam bukunya "Masa Depan Sempurna" bahwa tibanya perusahaan pendidikan menandai pendekatan kembali ke masa depan. Salah satu ciri utamanya ialah semangat menguji murid 
ala Victoria yang bisa menyenangkan Mr. Gradgrind dalam karya Dickens. Perusahaan-perusahaan ini harus membuktikan bahwa mereka memberikan hasil, bukan hanya bagi murid, tapi juga pemegang saham (John Micklethwait, 2007:166).

Di Indonesia, gerbang komersialisasi pendidikan - khususnya pendidikan perguruan tinggi - bergulir sejak bergabungnya Indonesia menjadi salah satu anggota dari World Trade Organization (WTO). Semenjak itu kepentingan pemerintah disesuaikan dengan kepentingan WHO. Misalnya pada tahun 2009 lahir Undang-Undang Badan Hukum Pendidikan (UU BHP) yang meregulasi tentang bentuk badan hukum lembaga pendidikan formal yang berbasis pada otonomi kampus dan nirlaba. UU BHP ini membuat lembaga pendidikan dikelola seperti perusahaan untuk keuntungan semaksimal mungkin. UU BHP cenderung meminimalisir negara bahkan menghilangkan kewajiban negara untuk mencerdaskan generasi muda dan menyediakan fasilitas pendidikan yang berkualitas.

Komersialisasi pendidikan berdampak semakin berkurangnya peran negara dan adanya otonomi kampus. Otonomi kampus menjadikan universitas layaknya perusahaan yang bebas mencari sumber keuangan mandiri. Akhirnya berbagai perguruan tinggi negeri (PTN) membuka pintu masuk seluas-luasnya bagi calon mahasiswa. Hal ini diterapkan oleh perguruan tinggi sebagai sarana penyerapan anggaran dari biaya masuk calon mahasiswa baru. Kebijakan ini membuat universitas lebih mengedepankan kuantitas dari pada kualitas.

\section{Bahaya Dunia Maya}

Peradaban manusia mengalami perubahan dari era agraris, bergeser ke era industri, dan sekarang menuju ke era digital. Para pakar dan pengamat media menilai bahwa abad ke-21 merupakan abad teknologi dan informasi, dimana umat manusia memasuki era "cyberspace" atau dunia tanpa batas. Era ini ditandai dengan informasi yang disebarluaskan melalui media massa akan secara signifikan menentukan arah perkembangan masyarakat 
Dunia maya selain sebagai sarana untuk mengakses informasi dengan mudah juga dapat memberikan dampak negatif bagi siswa. Terdapat pula, Aneka macam materi yang berpengaruh negatif bertebaran di internet. Misalnya: pornografi, kebencian, rasisme, kejahatan, kekerasan, dan sejenisnya. Berita yang bersifat pelecehan seperti pedofolia, dan pelecehan seksual pun mudah diakses oleh siapa pun, termasuk siswa. Barang-barang seperti viagra, alkohol, narkoba banyak ditawarkan melalui internet. Contohnya, 6 November 2018 lalu diberitakan salah seorang siswi SMA di Jawa Timur pergi meninggalkan sekolah demi menemui seorang lelaki yang dia kenal melalui situs pertemanan "facebook". Hal ini sangat berbahaya pada proses belajar mengajar.

Jaringan internet yang awalnya digunakan oleh instansi tertentu, secara cepat menjadi medium yang bisa digunakan oleh masyarakat luas. Bahkan akses terhadap internet tidak hanya semakin mudah melainkan juga semakin murah untuk dijangkau. Di Indonesia saja, pengguna internet dua tahun terakhir meningkat lebih dari 50\% yaitu 132 juta pengguna (APJII 2014). Yang lebih mencengangkan lagi adalah sebagian besar penggunanya adalah dari kalangan usia produktif dan pelajar.

\section{Ketergantungan}

Mesin-mesin penggerak globalisasi seperti komputer dan internet dapat menyebabkan kecanduan pada diri siswa ataupun guru. Sehingga guru ataupun siswa terkesan tak bersemangat dalam proses belajar mengajar tanpa bantuan alat-alat tersebut

Dengan merebaknya internet dan media sosial seakan manusia semakin tergantung hidupnya dengan kehadiran teknologi tersebut. Kesempatan untuk eksis di dunia tanpa batas menunjukkan bahwa siapa pun bisa membuat akun (komunitas) kapan saja dan apa saja. Tidak jauh berbeda pada masyarakat fisik (riil), di dunia virtual sangat mudah untuk membuat grup atau jejaring. Tidak jarang dari kita yang memiliki komputer dan smartphone yang terkoneksi dengan internet ternyata juga 
bergabung dengan grup dalam facebook, whatsapp, blackberry messanger, LINE, dan sejenisnya. Tidak ada hambatan atau kesulitan membuat suatu grup, berbagi info, dan mengundang orang lain untuk bergabung bahkan menanggapi diskusi. Inilah realita yang kita hadapi saat ini di era kemajuan teknologi informasi dan komunikasi.

\section{Pendidikan di Era Disrupsi}

\section{Peluang dan Tantangan Pendidikan}

Kegiatan belajar mengajar akan mengalami perubahan. Ruang kelas mengalami evolusi dengan pola pembelajaran digital yang memberikan pengalaman pembelajaran lebih kreatif, partisipatif, variatif dan menyeluruh. Fungsi guru pada era digital ini berbeda dibandingkan guru masa lalu. Kini guru/pendidik/ dosen tidak mungkin mampu bersaing dengan mesin dalam hal melaksanakan pekerjaan hafalan, hitungan, hingga pencarian sumber informasi. Mesin jauh lebih cerdas, berpengalaman dan efektif dibandingkan manusia, karen mesin tidak pernah lelah melaksanakan tugas.

Fungsi pendidik bergeser lebih pada mengajarkan nilai-nilai etika, budaya, karakter, kebijaksanaan, pengalaman, hingga empati sosial karena nilai-nilai itu yang tidak dapat diajarkan oleh mesin. Disrupsi bukan hanya soal mengganti kelas tatap muka konvensional menjadi kelas dunia maya. Namun yang lebih penting adalah revolusi peran pendidik sebagai sumber belajar atau pemberi pengetahuan menjadi mentor, fasilitator, motivator, bahkan ispirator dalam mengembangkan imajinasi, kreatifitas, karakter serta team work para generasi muda yang dibutuhkan pada masa depan.

Perubahan disruptif dalam dunia pendidikan terjadi karena perubahan cara mengajar yang telah berubah dari terpusat pada dosen/guru/pendidik menjadi berpusat pada siswa/peserta didik. Dengan perkembangan teknologi cara mengajar dan belajar dimungkinkan melewati batas-batas fisik ruang kuliah, 
kampus bahkan Negara (AIPI 2017).

Perkembangan metode tidak berhenti pada pengajaran yang berpusat pada mahasiswa. Saat ini dikenal konsep MOOCs (Massive Open Online Courses). Pengajaran online (daring) itu memiliki daya jangkau yang luas, melewati batas-batas fisik kampus dan negara. Sudah banyak perguruan tinggi terkemuka di dunia yang memberikan kuliah dengan memanfaatkan teknologi internet tersebut*. Bahan M00Cs dapat diakses siapapun dan diamanapun secara daring - bahkan gratis. Inilah perubahan yang sangat mendasar. Sebelumnya pembelajaran mensyaratkan kehadiran dikampus secara fisik dan membayar uang kuliah (tuition fees) yang sepadan dengan kualitas perguruan tinggi yang dituju.

M00Cs memungkinkan peminat "membeli eceran" mata kuliah, perguruan tinggi, dan profesor pengampu mata kuliah. MOOCs memeperkuat kedudukan "pembeli" sehingga mengubah "pasar" pendidikan tinggi dari "pasar penyedia" menjadi "pasar pembeli". Bila sekarang kurikulum program studi dirancang oleh perguruan tinggi, pada masa depan bisa jadi "pembeli" yang akan menentukan mata kuliah yang ingin dikutinya di universitas. Dengan kata lain, mereka akan membangun kurikulum pribadi yang tentunya akan sangat beragam. M00Cs inilah yang mengawali disrupsi perguruan tinggi dan bahkan keseluruhan sistem pendidikan tinggi. Mungkin belum dirasakan oleh banyak orang hari ini, tetapi lambat laun itu terjadi karena getaran-getarannya sudah merasuk.

Secara garis besar Kasali telah menjelaskan dengan detail dalam bukunya (Kasali 2018), bahwa universitas kelak akan menjadi sasaran disrupsi untuk merespon tuntutan global dan

* Di Indonesia upaya serupa serupa telah dirintis oleh sebuah lembaga bernama IndonesiaX sejak 2015 dan melibatkan para pengajar perguruan tinggi ternama. Usaha ini masih tahap awal, belum menjadi bisnis andalan perguruan tinggi. Program yang lebih maju adalah Program Universitas Terbuka yang dinamakan Program Sertifikat terbuka Online. Program in dikembangkan untuk memungkinkan peminat terus belajar sepanjang hayat pada era digital kini dan diamsa yang akan dating (AIPI 2017, 14). 


\section{Ali Fikri Cholil}

dunia digital. Kelak akan ada entrant yang mendisrupsi diri, lalu memimpin perubahan mendasar.

Ada beberapa gelombang disruptif dalam pendidikan meliputi :

a) "On demand" jasa-jasa pendidikan dan ketrampilan, termasuk perkuliahan ujian.

b) "Open source" jasa-jasa pendidikan dan ketrampilan.

c) Aplikasi-aplikasi pendidikan yang mobile dan responsif.

d) Kurikulum yang lebih bersifat personal dan "tailor made".

e) Layanan konten tanpa batas.

f) Platform pendidikan kolaboratif.

g) Kursus-kursus dan materi-materi gratis secara online.

\section{Nilai-Nilai Keislaman yang Meredup}

Dengan majunya peradaban manusia, banyak nilai-nilai keislaman yang meredup dan sedikit demi sedikit hilang dari peredaran. Antara lain adalah hilangnya sikap tanggung jawab keagamaan dan sosial (amanah) dari individu dan msyarakat. Amanah disini adalah kesediaan manusia untuk memikul beban keagamaan (takalif syar'iyyah) sebagaimana diamanatkan oleh Allah (lihat QS. Al Ahzab: 72, QS. Al A`raf : 172). Bentuk berkurangnya amanah pada individu dan masyarakat diantaranya : seperti ketidak patuhan untuk melaksanakan kewajiban agama, sikap acuh tak acuh kepada pendidikan agama pada anak-anak, korupsi merajalela, tidak diindahkannya nilai-nilai moral atau etika, hidup dalam suasana egoistis, menipisnya rasa empati kepada masyarakat yang kekurangan.

Saat ini, kehidupan umat manusia sangat dipengaruhi oleh falsafah kehidupan ala barat yang serba pragmatis. Hal ini berawal dari teori ekonomi liberal, kapitalisme, yang berimbas pada cara berpakaian, kesenian, budaya dan sebagainya. Secara objektif bahwa kemajuan teknologi telah membawa banyak kemaslahatan bagi kehidupan manusia. Namun, kemajuan duniawi semata tidaklah diinginkan oleh Islam. 
Nilai-nilai spiritual pada instrumen keagamaan belum bisa mengubah sikap dan mentalitas masyarakat. Banyaknya masjid dan musholla, banyaknya orang pergi haji, ternyata belum bisa banyak mengubah sikap orang islam. Nilai keagamaan seseorang masih ditentukan berdasarkan bentuk lahiriah semata. Padahal yang terpenting dalam kehidupan beragama adalah bagaimana nilai-nilai yang luhur itu bisa membumi ditengah-tengah masyarakat seperti keadilan hukum, keadilan ekonomi, keadilan sosial, semangat pluralitas (ta`addudiyah), ukhuwah (persaudaraan), baik ukhuwah islamiyah, ukhuwah insaniyyah, dan ukhuwah diniyah, sadar lingkungan, empati terhadap sesama, mau berbagi dan amal-amal sosial lainnya.

Dalam tataran ekonomi, teori ekonomi liberal menyebabkan kesenjangan yang cukup tajam antara negara kaya dan negara miskin, begitu juga antara kelompok orang kaya dan orang miskin pada suatu negeri. Sistem keuangan dunia ternyata tidak bisa menjadikan penduduk dunia bisa hidup dengan baik. Sistem kehidupan modern yang bertumpu pada sistem kapitalistik menyebabkan banyak kalangan cenderung mengejar materi dengan cara yang bertentangan dengan etika dan kadangkala tidak manusiawi.

Dalam tataran politik, hubungan antar negara berdasarkan kepentingan ekonomi semata, terutama dari kelompok negara-negara adikuasa. Bukan berdasarkan saling menolong dan berkeadilan. Kasus memilukan terjadi di Irak, Afganistan, dan Libya yang digasak habis-habisan dengan dalih memerangi terorisme atau membantu para revolusioner, tapi dibalik itu ada kepentingan lain, yaitu menguasai cadangan minyak dan gas bumi, demi masa depan ekonomi mereka. Hubungan antar negara menjadi tegang, ada ketidakadilan dalam menyelesaikan sengketa antar satu negara lainnya.

Dalam tataran budaya, kehidupan modern telah menyajikan satu model kehidupan yang "taharrur", cuek, semau gue, ekspresi yang acapkali kebablasan dan tidak lagi memperhatikan etika agama. Yang muncul kepermukaan adalah sikap hidup 
hedonistis atau sikap mementingkan unsur kedunian semata. Banyaknya tempat hiburan, bentuk hiuburan, mal-mal mewah, menandakan bahwa manusia ingin mencari kesenangan duniawi. Falsafah eksistensialisme telah menghantui kehidupan mereka. Inilah budaya yang diekspor ke negara-negara lain. Masyarakat yang tidak lagi punya pegangan dalam kehidupan mereka akan terbawa arus kehidupan seperti ini. Dengan kata lain, kehidupan modern tidak bisa menjamin kesejahteraan lahir dan batin masyarakat dunia.

\section{E. Nilai-Nilai Keislaman dalam Tata Dunia Baru yang Universal}

\section{Ketauhidan}

Tauhid adalah sebuah keniscayaan dalam kehidupan. Nilai ketauhidan sudah semestinya menjadi skala prioritas bagi tata dunia baru. Inilah inti dari ajaran agama samawi semenjak Nabi Adam sampai Nabi Muhammad. Tanpa prinsip tauhid ini, manusia telah melalaikan dzat yang menciptakan, mendidik, dan mengurus kehidupan mereka. Pengingkaran terhadap prinsip ini menyebabkan manusia terombang-ambing oleh kehendak hawa nafsu.

Persoalan yang dihadapi masyarakat berketuhanan di era modern adalah adanya pengingkaran terhadap keberadaan Tuhan dalam kehidupan mereka. Pengingkaran terhadap prinsip ini menyebabkan manusia terombang-ambing oleh kehendak hawa nafsu. Mereka menjadi budak hawa nafsu, harta benda, pangkat dan jabatan, dan sebagainya. Jiwa mereka tergadaikan dan terkungkung untuk itu semua. Hal ini akan menyebabkan manusia celaka.

Rasul ingin memberikan pelajaran bahwa materi bersifat sementara, mereka yang hasratnya hanya materi akan bertemu dengan kesenangan semu dan sementara. Yang dipentingkan adalah sisi lahiriah manusia saja. Padahal, kebahagiaan terletak pada suasana hati. Ini hanya mengakibatkan kesengsaraan. Seba- 
liknya Allah Maha kekal dan abadi. Bagi mereka yang hasratnya hanya kepada Allah, mereka akan mendapat kebahagiaan yang kekal.

Apa yang telah dikatakan nabi terbukti kebenarannya. Ternyata dinegara yang paling makmur dari segi materi seperti dinegara Eropa Barat, Jepang, Korea Selatan, dan Amerika kejadian bunuh diri cukup tinggi. Mereka hidup dalam kesengsaraan (ta is). Ini karena mereka tidak mempunyai sandaran teologis yang mampu menjawab persoalan kehidupan mereka (Muhammad 2017).

\section{Persamaan dan Persaudaraan}

Al Qur`an menandaskan bahwa manusia diciptakan oleh Allah untuk saling kenal mengenal. Baik mengenal secara pribadi maupun adat istiadat atau 'urf (Lihat QS. Al-Hujurat : 13). Ayat ini ditujukan kepada seluruh manusia tanpa melihat asal-usul mereka, baik dari segi agama, ras, golongan, dan sebagainya. Ayat ini juga berlaku secara individu maupun antar komunitas manusia. Semua manusia pada dasarnya adalah satu keluarga besar dari ayah dan ibu yang sama, yaitu Nabi Adam dan Siti Hawa. Oleh karena itu, semua manusia dijuluki Bani Adam atau anak cucu Nabi Adam. Kata ini terulang 7 kali dalam Al Qur`an. Dengan demikian, semua manusia adalah satu keluarga besar, satu saudara, dan satu rumpun kemanusiaan.

Sudah tentu persoalannya tidak terhenti sampai pada ta ‘ $a r u f$ atau saling kenal, tapi perlu ada kelanjutan yaitu ta `awun atau tolong menolong dalam kebaikan. Termasuk dalam hal kebaikan adalah tolong menolong dalam kemanusiaan seperti mendirikan sekolah, rumah sakit, panti sosial, sarana dan prasarana yang dibutuhkan masyarakat, dan sebagainya. Tindakan berikutnya adalah tanashuh atau saling memberikan nasehat, saling mengingatkan untuk berpegang teguh kepada kebenaran dan selalu bersabar dalam menghadapi semua persoalan. 


\section{Pluralitas}

Tawaran Al Qur`an kepada masyarakat adalah persoalan pluralitas atau keanekaragaman manusia dalam berbagai bentuknya. Persoalan ini telah mendapatkan legitimasi dari Al Qur`an, karena hal ini merupakan keniscayaan dalam hidup. Al Qur`an menyebutkan Pluralitas manusia dalam kebangsaan dan puak-puak (QS. Al Hujurat: 13), warna kulit dan bahasa (QS. Ar Rum: 22), agama (QS. Al Baqarah:256, QS. Yunus: 99, QS. Al Hajj: 78). Sebagaimana dijelaskan diatas bahwa adanya pluralitas manusia itu dalam rangka saling mengenal bukan saling memusuhi. Berbeda dalam hal agama bukanlah alasann untuk menyerang pemeluk agama lain. Al Qur`an memberi peluang kepada pemeluk agama lain selain agama islam untuk tetap memelihara tempat peribadatan meraka.

Al Qur`an juga menegaskan bahwa dalam hal beragama tidak ada paksaan. Tidak boleh seorang memaksakan kepada orang lain untuk memeluk agama dan keyakinan tertentu, keyakinan tidak bisa dipaksakan. Itu hak semua orang untuk memilih keyakinan yang akan dipeluknya. Manusia berkal sehat akan mengetahui mana keyakinan yang benar dan mana keyakinan yang salah atau bathil.

Salah satu bapak pluralisme indonesia adalah Abdurahman Wahid. Pluralisme Abdurahman Wahid berakar dari tradisi islam yang kuat yaitu studi referensial kitab suci dan pustaka ulama-ulama klasik. Disatu sisi pluralisme Abdurahman Wahid berdasar pada sebuah kemestian alamiah (sunnatullah) yang termaktub dalam kitab suci. Di sisi lain pluralisme Abdurahaman Wahid bisa menjadi counter atas keberagaman umat islam khususnya Indonesia yang semakin lama mengarah kepada eksklusivisme, tidak saja dari individu-individu umat islam tetapi juga dari organisasi kemasyarakatan (Iswahyudi 2016, 13). Abdurrahaman Wahid juga mengarahkan pluralismenya untuk kebhinekaan Indonesia yang berdasarkan pada asas kebangsaan. 


\section{Keadilan Hukum, Ekonomi, dan Sosial}

Al Qur`an memerintahkan kaum muslim untuk menegakkan keadilan, berbuat baik, memberi infak kepada sanak kerabat, melarang perbuatan keji dan munkar (QS. An Nahl: 90). Al Qur`an juga menegaskan bahwa keadilan mengakibatkan seseorang lebih dekat dengan ketakwaan seseorang (QS. Al Maidah; 8). Keadilan hukum harus ditegakkan walau berakibat buruk pada diri sendiri, kedua orang tua, dan sanak kerabat (QS. An Nisa: 135). Nabi menyebutkan bahwa ketidak adilan hukum akan mengakibatkan kehancuran suatu bangsa. Nabi mengatakan bahwa jika ada seseorang dari kelas bawah mencuri, mereka beramai-ramai menghukumnay. Namun, jika yang mencuri itu orang kelas atas mereka membiarkannya begitu saja. Apa yang disebutkan oleh nabi ternnyata terbukti pada masa kini.

Dalam keadilan ekonomi, Al Qur`an menyebutkan bahwa orang kaya yang mempunyai harta yang lebih perlu berbagi dengan mereka yang miskin, agar harta tidak bergulir diantar mereka saja. Dalam berbagai ayat, sifat memberi adalah satu indikator al-birr atau kebaikan seseorang (QS. Al baqarah : 177). Adanya kebajikan pembagian kekayaan dalam berzakat kepada fakir miskin dan lainnya adalah pintu masuk untuk melakukan upaya agar tidak ada lagi ketimpangan ekonomi pada masyarakat. Adanya ketimpangan ekonomi pada msayarakat akan menyebabkan kerawanan sosial yang tidak diinginkan oleh siapapun.

Dalam suatu hadis disebutkan bahwa kebaikan keislaman seseorang adalah jika dia senang memberikan makanan kepada orang lain dan menyapa orang lain, baik yang dikenal maupun tidak dengan memberikan salam. Pada saat yang lain, nabi ditanya tentang ciri-ciri haji yang mabrur. Nabi menjawab bahwa tanda haji mabrur adalah suka memberi makanan da berkata yang baik. Dalam kesempatan lain, Nabi pernah ditanya tentang ciri-ciri haji yang mabrur. Nabi menjawab bahwa tanda haji mabrur adalah suka memberi makanan dan berkata yang baik. Dari urain diatas dapat diambil kesimpulan bahwa islam adalah agama yang senantiasa mengajak peduli kepada orang lain. 


\section{Kedamaian dan Anti Kekerasan}

Islam adalah agama yang mengajak pengikutnya selalu menciptakan kedamaian diantara anggota masyarakat. Karena, kedamaian akan menciptkan stabilitas, stabilitas akan memberikan peluang untuk membangun masyarakat di seluruh seginya. Dalam Al Qur’an ada larangan untuk saling mengejek dan meremehkan antara satu kaum dan kaum lainnya, karena hal ini menjadi pemicu permusuhan. Al Qur`an melarang menggunjing, berprasangka buruk, mencari kesalahan atau aib orang lain $(\mathrm{QS}$. Al Hujurat: 12).

Al Qur`an juga mengajak kaum muslimin untuk berbuat baik (birr) dan berbuat adil kepada siapapun selama tidak memerangi dan mengusir kaum muslimin (QS. Al Mumtahanah : 8). Al Qur`an juga mengapresiasi mereka yang santun dalam berkata dan tidak terprovokasi oleh ejekan orang jahil (QS. Al Furqon: 63). Al Qur’an juga mengajak kaum muslimin untuk memilih jalan damai jika kelompok lain menginginkan hal itu (QS. Al Anfal:61).

Hal yang perlu diperhatikan disini adalah bahwa kedamaian yang dicanangkan islam tidak menafikan (meniadakan) adanya tindakan keras yang pernah dilakukan kaum muslimin pada masa lalu seperti peperangan melawan orang kafir, Persia, Romawi, dan sebagainya. Hal ini karena ada beberapa penyebab antara lain: adanya kedhaliman dan penindasan yang dilakukan mereka terhadap kaum muslimin. Baik pada saat Nabi dan sahabatnya masih di Makkah ataupun setelah berhijrah ke Madinah. Penyerangan kaum muslimin terhadap mereka juga terjadi karena adanya provokasi dari pihak lain yang akan menyerang kaum muslimin sebagaimana yang apa yang telah dilakukan oleh tentara Romawi pada perang Tabuk.

\section{Moderasi}

Al Qur`an menawarkan konsep moderasi (wasathiyah) dalam kehidupan, karena inilah yang sesuai dengan fitrah manusia. Dalam perilaku sehari-hari manusia juga menyenangi hal-hal yang bersifat moderat. Perilaku pemberani (Syaja`ah) 
adalah martabat antara penakut dan ngawur (tahawwur). Sifat pemurah adalah martabat antara sifat kikir dan boros. Selaku umat terbaik, umat islam dituntut untuk memperlihatkan prestasi mereka dalam ranah global, baik dari segi keilmuan, ekonomi, lingkungan hidup, sosial kemasyaraktan dan sebagainya. Diantaranya menjaga hubungan baik antar umat beragama. Berbuat baik (al birr) dan berkeadilan dengan semua manusia, selama tidak berbuat dhalim, adalah sesuatu yang diimbau oleh Al Qur`an.

Al Qur’an menyebutkan bahwa umat Nabi Muhammad adalah umat pertengahan (wasath). Kata wasath yang berarti pertengahan menunjukan keadaan terbaik. Karena tidak ke kanan dan tidak ke kiri. Karena posisinya berada di pertengahan, maka umat nabi Muhammad menjadi saksi atas umat-umat sebelumnya. Jika terjadi pelencengan dalam ajaran agama, umat Nabi Muhaamad yang dibekali Al Qur’an akan mengawasi dan membetulkannya.

Al Qur`an juga melarang kaum muslimin untuk bertindak berkelebihan dan keterlaluan dalam agama (ghuluww). Pada saat ini, ada kelompok yang menggunakan kekerasan terhadap pihak lain yang dianggap bertentangan dengan norma-norma agama tanap melihat latar belakang dan efek yang timbul dari tindakannya. Semua dilakukan atas nama agama, tapi ada juga kelompok yang sangat pasif dalam melihat keteledoran di masyarakat. Sikap yang baik adalah aktif melalukan pembenahan dalam internal umat yang dilakukan secara arif dan bijak.

\section{Akhlak Mulia}

Akhlak mulia adalah puncak tertinggi martabat seseorang. Dengan akhlak seseorang bisa merenggut hati orang lain. Dengan akhlak seseorang dekat dengan Allah. Akhlak adalah hiasan seseorang. Jika seseorang tidak bisa memberikan atau membagikan harta dan ilmunya kepada banyak orang, dia bisa memberikan akhlaknya kepada semua orang. Dengan akhlak dan hati nurani inilah kaum muslimin mendapatkan simpati dari penduduk 


\section{Ali Fikri Cholil}

negeri yang dulu dikuasai oleh romawi dan parsi. Dengan akhlak Nabi Muhammad berhasil merenggut masyarakat dunia dan menundukan mereka. Kemajuan teknologi tidak berarti apa-apa jika orang dibelakang kemudinya tidak berakhlak "The Man Behind The Gun."

Dalam surah al Isra` ayat 23-39, menjelaskan tentang dasar-dasar akhlak. Al Qur`an menjelaskan perilaku yang perlu diamalkan orang islam, baik terhadap dirinya, kepada orang dekat seperti keluarga, atau kepada orang lain. Jika surah ini diturunkan ketika Nabi belum hijrah, maka sebenarnya islam telah mencanangkan etika sangat mulia yang bisa dijadikan basis etika dalam pergaulan internasional. Ayat ini (Q.S. al Isra' ayat 23-39) menjelaskan tentang dasardasar akhlak. Ada beberapa perintah dan larangan, yaitu: 1) Perintah untuk beribadah hanya kepada Allah; 2) Berbuat baik kepada orang tua, ucapan atau perkataan; 3) Memberi santunan kepada sanak saudara, kerabat, kaum miskin, ibn sabil (musafir yang kehabisan ongkos); 4) Mengucapkan kata yang sopan jika tidak mau memberi kepada orang lain; 5) Tidak boleh menghamburkan harta; [6]. Santun terhadap orang tua ketika sudah sepuh; 7) Tidak boleh kikir dan tidak boleh memberikan harta secara berlebihan; 8) Tidak boleh membunuh anak-anak karena takut miskin; 9) Tidak boleh melakukan zina dan pendahuluannya; 10) Tidak boleh membunuh tanpa hak; 11) Tidak boleh memakan harta anak yatim; 12) Kewajiban menunaikan janji; 13) Jika menakar timbangan harus betul, tidak merugikan kepada pembeli; 14) Tidak boleh melakukan tindakan (memberikan fatwa, menghukum, berkomentar, dan lain-lain) tanpa dibekali pengetahuan yang cukup.

\section{F. Catatan Penutup}

Globalisasi tidak dapat dihindari oleh siapapun, kecuali dia menutup diri menjauhi interaksi dan komunikasi global dengan yang lain. Ada hal yang perlu disadari dan mendapat catatan tentang globalisasi. Globalisasi disamping membawa efek positif (manfaat), namun juga mendatangkan efek negatif (kerugian). 
Oleh karena itu, harus pandai dalam menyikapinya. Jika nilai-nilai yang terdapat dalam globalisasi itu positif, maka kita tidak ada salahnya apabila kita mengambilnya untuk diterapkan dalam kehidupan. Sebaliknya jika nilai-nilai dalam globalisasi itu negatif, maka kita harus menjauhinya dan menolaknya.

Dalam hal ini, ungkapan seperti al-akhdu bi al-jadid al-ashlah (ambillah hal-hal yang baru yang sekiranya baik dan banyak mengandung maslahat). Dengan kata lain, bagaimana agar nilai-nilai positif yang ada di Barat, atau bahkan di belahan negara lain bisa kita ambil. Budaya positif tersebut mencakup disiplin, kebersihan, tanggung jawab, kompetisi, kerja keras, penghargaan terhadap orang lain yang membutuhkan bantuan, demokratisasi, dan semacamnya. Sebaliknya, yang harus disadari globalisasi juga banyak mengandung hal-hal negatif

Tata dunia baru yang dicanangkan adalah aturan yang bisa menggabungkan antara dunia dan akherat, nilai-nilai agama samawi yang membumi, yang bisa memenuhi hajat ruhani dan jasmani, intelektual dan spritual, dibalut dengan akhlak mulia. Semua itu akan terlaksana jika kaum muslimin sendiri yang memulai dengan memahami dan menerapkan nilai-nilai keislaman.

\section{DAFTAR PUSTAKA}

AIPI, Tim. 2017. Era Disrupsi: Peluang Dan Tantangan Pendidikan Tinggi Indonesia. Jakarta: Akademi Ilmu Pengetahuan Indonesia.

Harahap, Syahrin. 2015. Islam Dan Modernitas: Dari Teori Modernisasi hingga Penegakan Kesalehan Modern. Jakarta: Prenada Media Group.

Iswahyudi. 2016. Pluralisme Islam Pribumi (Melacak ArgumenArgumen Abdurahman Wahid Tentang Pluralisme Islam di Indonesia. Yogyakarta: Nadi Offset.

Kasali, Rhenald. 2018. The Great Shifting: Ketika Platform Berubah Kehidupan dan Bisnis pun Berpindah. Jakarta: PT. Gramedia Pustaka Utama. 
Kasali, Rhenald. 2018. Disruption: Tak Ada Yang Tak Bisa Diubah Sebelum Dihadapi, Motivasi Saja Tidak Cukup. Jakarta: PT. Gramedia Pustaka Utama.

Koloay, RNS. 2016. "Perkembangan Hukum Indonesia Berkenaan dengan Teknologi Informasi dan Komunikasi." Jurnal Hukum 22 (5).

Muhammad, Ahsin Sakho. 2017. Keberkahan Al Qur'an: Memahami Tema-Tema Penting Kehidupan dalam Terang Kitab Suci. Jakarta: PT. Qaf Media Kreatif.

Nurhaidah, M. Insya Musa. 2015. "Dampak Pengaruh Globalisasi Bagi Kehidupan Bangsa Indonesia." Jurnal Pesona Dasar 3 (3): 1- 14.

Rooseno, Toeti Herati. 2018. "Budaya Manusia Indonesia di Era Disrupsi dan Globaliasasi." Materi Seminar KIS-AIPI, 4 September 2018, Universitas Padjajaran Bandung. 